ores of which are very rare, is being supplemented for medical and similar purposes by artificial radioactive elements, but substitutions of this kind are obviously very exceptional In the main, we can only look to a more economical use of metals and to more complete recovery as a means of conservation. Another fertilizer, phosphate, is mainly derived (apart from that which is a byproduct of the basic steel industry) from a few sources of limited extent, and our present highly inefficient means of dealing with sewage leads to the greater part of the phosphates being discharged into the sea. This is a form of waste which is closely linked with the general question of the fertility of the soil, and the problem will call urgently for a scientific solution in the very near future.

The case for a planned conservation of mineral resources may not seem so strong as that for energetic action to conserve soils and forests. Even minerals of which the known reserves are small may last for several generations. The future of the rarer and increasingly important elements is more difficult to foresee because of the imperfect survey so far made of their scattered deposits, but it is likely that the demand for them will increase more rapidly than that for the more common minerals. However, many of the errors of the past have come from lack of foresight, and a planned world economy must take account of conditions a century or more hence, when our descendants may find themselves hampered by the wasteful exploitation of natural resources in our own day.

That an international control of raw materials will be needed after the War is a natural consequence of such a promise as that of equal access contained in the fourth aim of the Atlantic Charter. A recent issue of Planning (P E P) has suggested a means by which such a control could be introduced, tentatively at first by application to a small number of commodities, the international raw materials union of producers including representatives of Governments in their capacity of consumers as well as producers. Such an authority would have many functions outside the scope of this paper, but as it would be in possession of the fullest information as to production, consumption and reserves it would be able to consider, in the light of that knowledge, the question of the possible exhaustion of reserves, and to recommend, or if its constitution should permit, to enforce, greater economy in use or a restriction of exploitation.

\title{
ECONOMIC ASPECTS OF THE BLOCKADE AND COUNTER-BLOCKADE
}

\section{By Paul Einzig}

$\mathrm{T}$ HE relative importance of the economic factor among the factors determining the outcome of the War has increased considerably as a result of the progress in the mechanization of the armed Forces. Requirements of weapons and equipments of raw materials necessary for their manufacture and of motor fuel are now incomparably larger and more diversified than they were during the War of 1914-18. The striking power of the armed Forces is now dependent on the industrial capacity and the importing capacity of the belligerent countries to a much higher degree than in previous wars. The belligerent countries are now incomparably less self-sufficient than they were in the past. For this reason the duration and outcome of the present War depends to a very large extent on the results of blockade and counter-blockade.

It is essential to avoid exaggerating the relative importance of economic warfare ; but it is equally important to avoid going to the other extreme. The exaggeration of the relative importance of the blockade during the early months of this War was largely responsible for the slackness of Great
Britain's war effort in other directions during that period. After the disillusionment that followed the German victories in Western Europe, the pendulum swung in the opposite direction, and for some time it was all but generally believed that economic warfare in general and blockade in particular was incapable of producing any noteworthy results. The truth lies somewhere half-way between the two extremes. In order to defeat Germany it is indispensable to win a decisive military victory. Such a victory is inconceivable, however, unless and until Germany's vital economic resources have been materially reduced as a result of offensive economic warfare. It is an equally essential condition of victory that offensive economic warfare waged by Germany in the form of counter-blockade and air bombing should be prevented from reducing Great Britain's economic resources.

The argument of those who underrate the importance of offensive economic warfare among our weapons against Germany runs broadly as follows :

The relative extent to which Germany's economic resources can possibly be affected either by air 
bombing. or blookade is moderate. Germany's industrial capacity is so vast, her plants and stocks are so widely dispersed over the territory of the Reich and of the occupied countries, that the R.A.F. would be incapable of destroying more than a relatively small fraction of these resources. As for the blockade, its significance has become materially reduced as a result of the acquisition of new sources of raw material through the conquest of the greater part of Europe, and as a result of the development of the production of synthetic materials. There is a great deal of truth in this contention. It seems an altogether hopeless task to try to reduce Germany's economic war potential in general by means of an economic offensive. On the other hand, it is by no means beyond the realms of possibility to reduce certain key resources of Germany.

During the earlier phases of the War it was hoped that the German war machine could be paralysed by concentrating upon the reduction of German stocks of oil, rubber, textiles and rare metals such as tungsten, molybdenum, wolfram, etc., required for hardening steel. In the meantime, this list became shorter, partly because Germany succeeded in seizing large stocks of special metals and partly because the necessity for concentrating on a small number of materials had become obvious. Indeed, in my own view, maximum results could be achieved by simply concentrating on oil. Assuming that Germany will be unable to seize the Russian oilfields - or at any rate that even if she should seize them they would be in a hopelessly damaged condition-there is every reason to hope that the British economic offensive would be able to paralyse the German war machine and economic system by bringing about a reduction of Germany's oil supplies. While in most other respects the blockade does not inflict upon Germany an intolerable burden, in respect of oil it is capable of preventing almost completely the arrival of consignments from outside Europe. Moreover, if the air offensive is concentrated upon the oilfields under German control in Poland, Rumania, etc., and on synthetic oil plants, refineries, storage tanks and pipelines, then Germany's producing capacity and stocks could be materially reduced. By pursuing such a policy, economic warfare would be made to play a decisive part in preparing the ground for military victory.

Hitherto we have confined ourselves to examin. ing the possibilities of Allied offensive economic warfare against Germany. Let us now consider the problem of the defence against German offensive economic warfare. The British economic system has no Achilles' heel comparable to the German oil position, for the simple reason that so long 2,8 mastery of the sea is retained, deficiencies in particular materials can be made good by importing from overseas. For this reason, while German air bombing is capable of inflicting considerable losses upon life and property, it is in itself incapable of paralysing the British war machine and economic system in the same way as British air bombing is capable of paralysing the German war machine and economic system if concentrated upon oil production and supplies. The only way in which German economic warfare against this country could play a decisive role would be through cutting off Great Britain's lifeline. This is exactly the object of the German counter-blockade.

While Germany largely relies upon the production of food and raw materials of conquered Europe, Great Britain depends to an even larger extent on economic assistance from the United States and from the British Dominions. Neither of the belligerents is able to prevent the other from making use of these vast auxiliary resources outside their own territory. Judging by the progress to date of the Battle of the Atlantic, the German counter-blockade has so far failed to achieve this end. Judging by the expenditure of vast quantities of oil by Germany in the offensive against Russia, the results of the British economic offensive in the restricted sphere of oil have also been far from complete. These facts do not, however, prove that the economic weapon is of relatively small importance. After all, during the War of 1914-18, it took four years for the British blockade to produce its full effect upon Germany. It would be unduly optimistic to assume that the Battle of the Atlantic has been won and that Germany is entirely incapable of preventing Great Britain from benefiting by American and other overseas economic assistance ; and the mere fact that certain statements concerning the effect of the British blockade on the German oil position have since proved to be at least premature does not mean that sooner or later the British economic offensive will not deprive Germany of her vital oil supplies.

Blockade and counter-blockade tend to produce a profound effect upon the economic structure. The result of the British blockade is an intensification of the German self-sufficiency drive, and its extension over German-controlled Europe. Under the necessity of war requirements many new branches of production are established and existing ones are expanded. The German counter-blockade affects the British economic system in a different way. It is true that in some respects self-sufficiency is aimed at in order to economize in shipping space. For example, in Great Britain food production tends to increase, largely as a result of the German counter-blockade. The same factor also works, however, in the opposite sense. It requires less 
shipping space to import the finished products than to import raw materials required for their production. Partly for this reason many new plants have been established in the British Dominions in preference to their being built at home. In order to reduce the dependence of the British Forces in the Middle East and the Far East upon the lifelines from Great Britain, exposed as they are to German attacks, munition industries have sprung up in India, Australia and New Zealand. These Dominions are unable to depend on imports from Great Britain, and tend to become much more self-sufficient through the development of industries of their own.

The same is true concerning neutral countries. Lack of shipping space, among other reasons, prevents Great Britain from supplying her LatinAmerican markets to the same extent as before. The British blockade prevents these countries from buying manufactures from Germany, Italy, or other German-controlled industrial countries. Nor are the United States or Japan in a position to fill the gap. Consequently, blockade and counterblockade leads to the industrialization of LatinAmerica. In any event, since the blockade and counter-blockade have made it more difficult for the Argentine, Brazil, etc., to sell their products either in German-controlled Europe or in Great Britain, they could ill afford to keep up their imports at pre-war level.

It seems probable that to a very large degree these effects of blockade and counter-blockade will be of a lasting nature. This was the case with the economic effects of the Continental system and the British retaliatory measures adopted during the Napoleonic wars, and also with the effects of blockade and counter-blockade during the War of 1914-18. It is true, there is a great deal of idealistic agitation in favour of free trade after the War. The fact, however, that by the termination of hostilities the degree of international division of labour will be much smaller than it was in 1939 will have to be borne in mind. Overseas countries will be reluctant to de-industrialize themselves. Most countries will be anxious to retain and develop industries required for national defence. As for Great Britain, the permanent loss of many of its overseas markets and the decline of its income from overseas investments will make it necessary to continue to produce at home more food than it did before the War. The task of 'unscrambling the eggs' by demobilizing new industries abroad and by letting the millions of newly sown acreage in Great Britain go once more out of cultivation will be more difficult than is generally realized.

The lessons learnt from experience in economic warfare during this War are likely to influence the peace terms. The victors will want to disarm their vanquished opponent not only in a military sense but also in an economic sense. The reversal of Germany's trend towards self-sufficiency would provide some safeguards against another war; a compulsory demobilization of some of her industries producing synthetic key materials would go a long way towards discouraging a repetition of 1914 and 1939 , simply by rendering Germany more vulnerable to blockade.

\section{SEISMOLOGY AND EARTHQUAKE-PROOF DESIGN}

\section{By ERnest Tillotson}

$\mathrm{O}^{\mathrm{N}}$ N May 7, 1940, Mr. D. Laugharne Thornton read a paper on "Earthquakes and Struc-" tures" to the Royal Society of Arts ${ }^{1}$, in which he stressed the need for the co-operation of engineers and seismologists for the purpose of mitigating the effects of earthquakes on buildings. Mr. Thornton's paper showed that engineers are fully alive to the situation, while the work seismologists have been doing to this end is perhaps not generally realized. Most of the work has been done with actual earthquakes, though much useful information has been obtained by the use of shaking tables and artificial earthquakes caused by dynamite explosions. (The results might be of immediate use in 'bombproof' design.) As Great Britain is an island in which strong earthquakes are rare, adequate results would not repay the setting up of strong-motion instruments, and most results have, therefore, been obtained in the United States and Japan. Mr. Thornton stated in his paper that "the first great earthquake in which scientists were ready with a wide distribution of instruments including some capable of recording strong motion, occurred so recently as September 1, 1923, at Kwanto, Japan". It may well be that the first adequate and reliable results for certain purposes were obtained then, though ever since the time when Milne and Knott were in Japan valuable information has been accumulating. Certain institutions and individuals have also long been obtaining noteworthy results in the United States, though it was late in 1932 when the U.S. Coast and Geodetic Survey inaugurated a programme of recording strong ground movements in seismically 